\title{
GAMBARAN PENYEMBUHAN LUKA POST OPERASI \\ SECTIO CAESAREA DENGAN PEMBERIAN ANTIBIOTIK CEFTIZOXIME SEBAGAI PROFILAKSIS DOSIS TUNGGAL DI RUMAH SAKIT SINGAPARNA MEDIKA CITRAUTAMA KABUPATEN TASIKMALAYATAHUN 2018
}

\section{OLEH :}

\author{
Wulan Anggraeni, Hj. Yulia Herliani, SST,M.Keb, Etin Rohmatin, SST,M.Kes \\ (yanx0383@yahoo.co.id)
}

\section{A. ABSTRAK}

Kematian tersebut adalah infeksi pasca persalinan. Persalinan dengan Sectio Cesarea/SC memiliki resiko lebih besar mengalami infeksi dibandingkan persalinan normal. Upaya untuk mencegah terjadinya infeksi pasca persalinan dengan SC adalah dengan memberikan antibiotika profilaksis sebagai pencegahan Infeksi Luka Operasi

Tujuan penelitian ini untuk mengetahui pemberian antibiotik ceftizoxime sebagai profilaksis dosis tunggal terhadap penyembuhan luka operasi pada ibu post operasi sectio caesarea

Jenis penelitian ini menggunakan eksperimental quasi (semu). Rancangan yang digunakan adalah post test only design. Sampel adalah ibu bersalin dengan sectio caesarea di RS SMC Kabupaten Tasikmalaya pada bulan Oktober-November tahun 2018 sebanyak 53 orang yang diperoleh dengan teknik purposive sampling. Data diperoleh dengan menggunakan Format isian.

Hasil penelitian diperoleh seluruh ibu bersalin (100\%) diberikan antibiotik ceftizoxime sebagai dosis tunggal pada ibu pre operasi sectio caesarea. Penyembuhan luka operasi ibu pre operasi sectio caesarea pada hari ketiga sebagian besar termasuk kategori sembuh (83\%).

Kesimpulan dari penelitian ini adalah pemberian antibiotik ceftizoxime berpengaruh terhadap penyembuhan luka operasi sectio caesarea. Oleh karena itu, tenaga medis dapat menggunakan antibiotika profilaksis ceftizoxime pada prosedur SC untuk mencegah infeksi dan mempercepat penyembuhan luka.

\section{Kata Kunci ： Sectio caesarea, ceftizoxime, infeksi}

\section{B. PENDAHULUAN}

Perkembangan upaya peningkatan kesehatan secara menyeluruh dan berkesinambungan menjadi salah satu pilar utama membangun suatu daerah. Realisasi pembangunan kesehatan Indonesia dilaksanakan dalam bentuk upaya-upaya kesehatan yang ditetapkan berdasarkan standar pengukuran atau indikator kesehatan. Adapun indikator utama untuk mengukur derajat kesehatan masyarakat salah satunya adalah kesakitan dan kematian Ibu (AKI) (WHO, 2014).

Salah satu penyebab tingginya kesakitan dan kematian ibu adalah infeksi setelah persalinan. Diantara infeksi tersebut, infeksi luka operasi (ILO) merupakan infeksi yang sering terjadi pada pasien pasca pembedahan. Survey World Health Organization (WHO) melaporkan bahwa angka kejadian ILO di dunia berkisar antara (5\%) sampai (15\%) (WHO, 2015). Data WHO menunjukkan bahwa sekitar (5\% $34 \%$ ) dari total infeksi nosokomial adalah 
ILO (Haryanti dkk, 2013). National Nosocomial Infection Surveillace (NNIS, 2010) United States America mengindikasikan bahwa ILO merupakan infeksi ketiga tersering yang terjadi di rumah sakit sekitar $14-16 \%$ dari total pasien di rumah sakit mengalami ILO (Setyarini, Barus \& Dwitari, 2013).

Menurut Kemenkes RI tahun 2016 angka kejadian ILO pada rumah sakit pemerintah di Indonesia sebanyak $(55,1 \%)$ (Asyifa, Suarniant \& Mato, 2017). Hasil penelitian Yuwono (2013), membuktikan bahwa angka kejadian ILO di RS Dr. Mohammad Hoesin (RSMH) Palembang sebanyak $(56,67 \%)$ yang terdiri dari ILO superfisial incision (70,6\%), ILO deep incision (23,5\%) dan ILO organ (5,9\%). ILO ditemukan paling cepat hari ketiga.

Infeksi luka operasi terjadi pula pada persalinan dengan sectio caesarea. Persalinan sectio caesarea adalah teknik untuk melahirkan janin dengan membuka dinding perut dan dinding rahim. Pada pelaksanaanya, sectio caesarea memerlukan antibiotika profilaksis yang diberikan pada penderita yang menjalani pembedahan, sebelum terjadi infeksi atau pencegahan Infeksi Luka Operasi (ILO). Operasi sectio caesarea merupakan operasi bersih dari kontaminasi, sehingga pemilihan antibiotika profilaksis harus disesuaikan dengan standar yang ada (antibiotic guidlines, dll).

Wanita yang melakukan bedah sectio caesarea akan memiliki resiko (5\% -20\%) terjadinya infeksi yang berhubungan dengan kesehatan vagina, dan terjadinya komplikasi infeksi setelah menjalani operasi sectio caesarea merupakan hal yang substansial dan penting karena menyebabkan morbiditas maternal (Smaill \&Hofmeyr, 2007)

Tingginya kejadian ILO pada pasien pasca pembedahan sectio caesarea maka tenaga kesehatan dituntut bertanggung jawab menjaga keselamatan klien di rumah sakit, salah satunya mengurangi angka kejadian ILO (Putra \& Asrizal, 2012). Menurunkan kejadian infeksi terkait dengan pencegahan ILO bisa dilakukan oleh pelayanan kesehatan pada pasien, petugas kesehatan, pengunjung serta fasilitas pelayanan kesehatan (Pandjaitan, 2015). Kejadian infeksi luka operasi pada umumnya disebabkan oleh bakteri/kuman yang mampu berinteraksi pada luka operasi yang ada di kulit. Beberapa faktor yang mempengaruhi penyembuhan luka adalah faktor lokal yang terdiri dari oksigenasi, hematoma, teknik operasi. Faktor umum terdiri dari usia, nutrisi, steroid, keadaan luka, infeksi, sepsis dan obat obatan (Subiston, 2009). Faktor lainnya adalah gaya hidup klien dan mobilisasi (Kozier, 2012).

Kejadian infeksi luka post operasi menjadi penting oleh karena dipandang dari segi pasien akan memanjangnya waktu penyembuhan, kesakitan bahkan kematian. Selain itu kualitas hidup pasien baik fisik maupun psikis akan terganggu atau berubah secara permanen ditambah lagi dengan hilangnya waktu yang produktif bagi pasien. Dipandang dari segi rumah sakit infeksi luka post operasi akan menyebabkan pemborosan waktu dan fasilitas rumah sakit. Dipandang dari manajemen rumah sakit, besarnya angka kejadian infeksi luka operasi merupakan indicator mutu pelayanan. Dipandang dari segi pembiayaan infeksi luka post operasi merupakan beban tambahan bagi pasien maupun perpanjangan hari perawatan ( Suwardiman, 2007).

Salah satu upaya dalam mencegah infeksi pasca sectio caesarea adalah dengan penggunaan antibiotik profilaksis. Penggunaan antibiotik profilaksis pada masa prabedah ditujukan untuk menanggulangi infeksi agar resiko pasca pembedahan dapat ditekan serendah mungkin. Dalam hal ini, bila pembedahan ditunda, biasanya infeksi diatasi dahulu dengan pemberian antibiotik profilaksis sehingga secara khusus antibiotik diberikan dengan tujuan pencegahan infeksi pasca bedah. Pemberian antibiotik sistemik profilaksis biasanya sangat bermanfaat. Terdapat beberapa bukti bahwa penggunaan antibiotik profilaksis dapat mengurangi berkembangnya infeksi.

Antibiotik profilaksis telah terbukti menurunkan insiden morbiditas demam yang berkaitan dengan adanya endometritis, 
infeksi luka operasi, dan infeksi saluran kemih. Lain halnya dengan antibiotika profilaksis, antibiotika untuk terapi disarankan diberikan pada pasien post sectio caesarea, karena pasien caesar rentan terhadap bakteri yang timbul dari luar maupun dalam. Adanya infeksi post sectio caesarea yang berupa endometritis dan infeksi luka bedah dapat dinilai dari tanda tanda klinis berupa kenaikan suhu tubuh lebih dari $38^{\circ} \mathrm{C}$, uterus lembek dan nyeri tekan, luka berbau atau adanya eritema, pus, adanya indurasi atau infiltrate disertai nyeri tekan, dan kadang - kadang luka operasi terbuka (Mivumbi, 2014). Menurut teori tepi luka bagian luar secara normal terlihat mengalami inflamasi pada hari ke-2 sampai hari ke-3, tetapi lama kelamaan inflamasi ini akan menghilang dalam waktu 7-10 hari luka dengan penyembuhan normal akan terisi sel epitel dan bagian pinggirnya akan menutup. Apabila terjadi infeksi tepi luka akan terlihat bengkak dan meradang (Kozier, 2012).

Hasil penelitian yang dilakukan oleh Mutmainah (2014) dalam penelitiannya menemukan bahwa antibiotik profilaksis yang digunakan adalah ampisilin (24\%), ampisilin-sulbaktam (23\%), seftriakson $(19,5 \%)$, sefotaksim $(16 \%)$, amoksisilinklavulanat (11\%), dan sefazolin (6,5\%). Ditemukan kesesuaian pemilihan obat dengan standar WHO (30,5\%), yang meliputi tepat dosis $(6,5 \%)$ dan tepat waktu pemberian $(52 \%)$. Penggunaan antibiotik $100 \%$ efektif untuk mencegah luka infeksi setelah operasi.

Kemudian penelitian Nuraliyah (2012) menemukan bahwa hasil evaluasi kesesuaian penggunaan antibiotik profilaksis menunjukan bahwa dosis, cara dan waktu pemberian menunjukan kesesuaian sebesar $100 \%$ jenis antibiotik profilaksis yang digunakan terdapat kesesuaian (26,79\%).

Hasil studi pendahuluan yang dilakukan pada bulan September 2018 yang diperoleh dari Instalasi Rekam Medis RS SMC Tasikmalaya didapatkan bahwa pada tahun 2017 didapatkan sebanyak 16 kasus $(1.3 \%)$ post sectio caesarea mengalami komplikasi pembedahan ILO dari 1244 persalinan section caesarea, kemudian pada tahun 2018 (periode Januari sampai Agustus) didapatkan angka kejadian ILO sebanyak 6 kasus $(1 \%)$ dari jumlah ibu persalinan sectio caesarea mencapai 605 orang.

Data lain ditemukan adanya kasus infeksi pada ibu bersalin pasca sectio caesarea yang ditemukan pada 7 hari setelah persalinan yaitu sebanyak 3 kasus, sebanyak 2 ibu post sectio caesarea yang mengalami brach pada luka operasi. Selanjutnya pemberian antibiotika pada pasien pre operasi section caesarea di RS SMC Tasikmalaya menggunakan jenis cefotaxime dan cetriaxone diberikan 30 menit sebelum dilakukan tindakan section caesarea dengan dosis 1 gr kemudian dilanjutkan dengan pemberian terapi empiris. Pada akhir-akhir ini, pemberian antibiotik pada ibu pre operasi section caesarea dengan ceftizoxime dosis tunggal.

Ceftizoxime sebagai dosis tunggal merupakan kelompok obat yang disebut cephalosporin antibiotics dengan pola pemberian yang digunakan satu kali sudah mampu memberikan efek terafi dengan efektif secara klinik. Ceftizoxime bekerja dengan cara mematikan bakteri dalam tubuh. Ceftizoxime digunakan untuk mengobati berbagai jenis infeksi bakteri akibat persalinan dengan sectio caesarea.

Berdasarkan uraian tersebut, maka penulis tertarik untuk melakukan penelitian mengenai gambaran penyembuhan luka operasi sectio caesarea dengan pemberian antibiotik ceftizoxime sebagai profilaksis dosis tunggal di RS SMC Tasikmalaya.

\section{METODOLOGI PENELITIAN}

Penelitian ini merupakan penelitian eksperimental dengan jenis ekperimental quasi (semu). Penelitian eksperimental adalah suatu prosedur penelitian yang dilakukan dengan memberikan perlakuan/intervensi pada subjek penelitian, dengan tujuan melihat gambaran suatu perlakuan pada variabel independen terhadap variabel dependen. Metode dalam penelitian ini adalah metode deskriptif korelasional yang menggambarkan hasil akhir dari intervensi yang dilakukan. 
ini adalah :

Populasi dan sampel dalam penelitian

1. Populasi

Populasi dalam penelitian ini adalah ibu bersalin dengan operasi section caesaria di RS SMC Kabupaten Tasikmalaya periode Oktober November tahun 2018 dengan estimasi berjumlah 115 orang.

2. Sampel

Sampel dalam penelitian ini adalah ibu pre operasi section caesarea di RS SMC Kabupaten Tasikmalaya, teknik sampling yang digunakan adalah dengan purposive sampling yaitu pengambilan data pada ibu pre operasi section caesarea yang dilakukan dengan pemberian kriteria/selektif.

3. Cara pengambilan sampel

Sampel adalah sebagian yang diambil dari keseluruhan objek penelitian dan dianggap mewakili populasi (Notoatmojo, 2010).

Rumus Slovin :

$$
\begin{gathered}
n=\frac{N}{1+N\left(d^{2}\right)} \\
n=\frac{115}{1+115\left(0,1^{2}\right)} \\
n=\frac{115}{1+115(0,01)} \\
n=\frac{115}{1+1,15} \\
n=\frac{115}{2,15}
\end{gathered}
$$

$$
\mathrm{n}=53.4 \text { dibulatkan menjadi } 53 \text { orang }
$$

Sehingga diperoleh jumlah responden dalam penelitian ini adalah 50 orang.

a. Kriteria Inklusi

1) Ibu bersalin dengan $\mathrm{SC}$ terencana/elektif

2) Jenis $\mathrm{SC}$ menggunakan transpertoneal profunda

3) Pemberian antibiotik ceftizoxime $<2$ jam sebelum sayatan

b. Kriteria eksklusi

1) Ibu bersalin dengan KPD

2) Ibu bersalin dengan diabetes melitus

3) Ibu yang tidak bersedia menjadi responden

4) Adapun instrumen yang digunakan dalam penelitian ini adalah lembar format observasi (daftar tilik). Yaitu dengan menggunakan observasi pada ibu post sectio caesarea ke RS SMC Kab. Tasikmalaya untuk mengetahui proses penyembuhan luka dilakukan pada hari ke tiga.

5) Analisis data yang digunakan adalah berupa univariat yaitu menilai penyembuhan luka post sectio caesarea yang diberi antibiotik ceftizoxime sebagai profilaksis dosis tunggal pada ibu pre operasi sectio caesarea di RS SMC Tasikmalaya. Analisis statistik deskriptif untuk intervensi menggunakan distribusi frekuensi.

\section{HASIL PENELITIAN}

1. Pemberian antibiotik ceftizoxime sebagai profilaksis dosis tunggal pada ibu pre operasi sectio caesarea

Pemberian antibiotik ceftizoxime sebagai profilaksis dosis tunggal pada ibu pre operasi sectio caesarea di RS SMC Tasikmalaya

\begin{tabular}{lll}
\hline $\begin{array}{c}\text { Pemberian } \\
\text { Ceftizoxime }\end{array}$ & Jumlah & Persentase \\
\hline Ya & 53 & 100 \\
\hline Bukan & 0 & 0 \\
\hline Jumlah & $\mathbf{5 3}$ & $\mathbf{1 0 0}$ \\
\hline
\end{tabular}


Berdasarkan tabel 4.1 menunjukkan bahwa ibu bersalin sebelum dilakukan SC semunya (100\%) diberikan Ceftizoxime.

2. Penyembuhan luka ibu post operasi sectio caesarea di RS SMC Tasikmalaya.

Penyembuhan luka ibu post operasi sectio caesarea di RS SMC Tasikmalaya

\begin{tabular}{lll}
\hline Penyembuhan luka & Jumlah & Persentase \\
\hline Sembuh & 44 & 83.0 \\
\hline Belum Sembuh & 9 & 17.0 \\
\hline Jumlah & $\mathbf{5 3}$ & $\mathbf{1 0 0}$ \\
\hline
\end{tabular}

Berdasarkan tabel 4.2 menunjukkan bahwa ibu post SC dengan luka SC sudah sembuh sebanyak 44 orang $(83.0 \%)$, sedangkan yang belum sembuh sebanyak 9 orang $(17.0 \%)$.

\section{E. PEMBAHASAN}

1. Pemberian Ceftizoxime

Berdasarkan hasil penelitian menunjukkan bahwa ibu bersalin sebelum dilakukan SC seluruhnya $\quad(100 \%) \quad$ diberikan Ceftizoxime. Melihat dari data hasil tersebut didapatkan sebagian besar antibiotik yang diberikan adalah ceftizoxime, hal ini disebabkan karena pemberian antibiotik tersebut merupakan suatu hal yang baru diterapkan di rumah sakit SMC. Walaupun dalam penelitian terdapat ibu bersalin diberikan antibiotik selain dari ceftizoxime seperti cefotaxime. Pemberian antibiotik tersebut merupakan salah satu upaya untuk menekan angka kejadian komplikasi infeksi setelah prosedur bedah kebidana. Banyak hal telah dilakukan untuk mempelajari pengaruh antibiotik profilaksis dalam mengurangi morbiditas penyakit infeksi. Kebanyakan jenis antibiotik, jadwal dosis, dan rute administrasi telah diselidiki. Telah pula didapatkan bukti untuk mendukung penggunaan antibiotik profilaksis untuk sejumlah prosedur dalam kebidanan.

Meningkatnya resistensi antibiotik ini terutama diakibatkan oleh penggunaan antibiotik yang tidak tepat. Pemberian terapi antibiotik yang tidak tuntas dan penggunaan yang tidak perlu dari rejimen spektrum yang lebih luas memainkan peran penting. Baik pedoman pengobatan dan pedoman profilaksis membantu dalam mengurangi kemungkinan infeksi dan resistensi antibiotik. Kepatuhan dokter terhadap pedoman profilaksis antibiotik sangat beragam dan biasanya bertentangan dengan pedoman yang telah dipublikasikan.

Tujuan pemberian antibiotik ceftizoxime adalah antibiotik diberikan secara tunggal bertujuan untuk menekan angka kejadian infeksi dan mempercepat proses penyembuhan luika operasi. Walaupun sebenarnya profilaksis tidak mencegah infeksi yang disebabkan oleh kontaminasi pasca operasi. Penggunaan antibiotik profilaksis berbeda dari pengobatan dengan antibiotik dimana antibiotik profilaksis ini dimaksudkan untuk mencegah infeksi, sedangkan pengobatan antibiotik dimaksudkan untuk mengatasi infeksi yang sudah ada, biasanya membutuhkan waktu terapi yang lebih lama.

2. Penyembuhan luka post operasi sectio caesarea

Berdasarkan hasil penelitian didapatkan bahwa ibu post SC dengan luka SC sudah sembuh sebanyak 44 orang (83.0\%), sedangkan yang belum sembuh sebanyak 9 orang (17.0\%). Berdasarkan analisa peneliti bahwa mayoritas 
responden post operasi sectio cesarea memiliki proses penyembuhan luka yang sembuh, hal tersebut terlihat pada luka sectio pasien yang tidak terlihat adanya tanda-tanda infeksi seperti luka tidak tampak mengeluarkan pus, tidak bengkak, tidak kemerahan, tidak terasa panas, tidak terjadi perubahan pada daerah luka, dan tidak tampak keluarnya pembuluh darah pada daerah luka, hal tersebut sesuai dengan teori menurut Dini Kasdu yang menyatakan bahwa proses penyembuhan luka pasien post operasi sectio cesarea dikatakan sembuh jika luka tidak terdapat tanda-tanda infeksi selama masa perawatan 3 hari.

Menurut Benson (2009) sewaktu insisi (kulit diiris), maka beberapa sel epitel, sel dermis dan jaringan kulit akan mati. Ruang incisi akan diisi oleh gumpalan darah dalam 24 jam pertama akan mengalami reaksi radang mendadak. Dalam 2-3 hari kemudian, exudat akan mengalami resolusif proliferasi (pelipatgandaan) fibroblast mulai terjadi, pada hari ke-3-4 gumpalan darah mengalami organisasi.

Dari hasil penelitian menunjukkan bahwa lama penyembuhan luka bervariasi. Hal ini dipengaruhi beberapa faktor internal dan eksternal seperti teori yang dikemukakan oleh potter (2005) bahwa penyembuhan luka secara normal dipengaruhi oleh faktor nutrisi yang tepat, usia, merokok, dan sosial budaya (pantang makanan dan pemakaian gurita).

Hasil penelitian ini sesuai dengan penelitian yang dilakukan oleh Salamah (2015) yang menemukan bahwa Luka post sectio caesarea pada ibu post sectio caesarea di Rumah Sakit Panembahan Senopati Bantul tahun 2015 sebagian besar sudah pulih $(86,1 \%)$. Hasil penelitian ini lebih tinggi dibanding dengan hasil penelitian yang dilakukan Angriani (2014) yang menemukan $73,3 \%$ pasien di RSUD Salewangang Maros telah sembuh.

Menurut pendapat peneliti respon penyembuhan terhadap luka bervariasi sesuai dengan kondisi individu dan faktor-faktor yang mempengaruhinya sehingga praktisi kesehatan khususnya bidan harus mampu melakukan observasi atau pemantauan dengan seksama terhadap luka post SC serta faktor-faktor yang mempengaruhinya. Hal ini sesuai dengan teori praktik dasar Helen Baston yang menyatakan bahwa proses penyembuhan luka pada pasien post operasi sectio cesarea sangat dipengaruhi oleh faktor nutrisi, mobilisasi dan personal hygine, dimana faktor tersebut memiliki kemampuan untuk mempercepat penyembuhan luka pasien post sectio cesarea dan jika kebutuhan ketiga faktor tersebut terpenuhi terhadap proses penyembuhan luka pasien, maka pasien diperbolehkan kembali pulang kerumah dengan diberikan penyuluhan tentang perawatan luka yang akan dilakukan oleh pasien.

Melihat dari data tersebut penulis berpendapat bahwa adanya perbedaan waktu penyembuhan luka operasi sectio caesarea pada ibu yang diberikan ceftizoxime dibandingkan dengan ibu yang bukan diberikan ceftizoxime. Hal ini mengindikan bahwa antibiotik profilaksis telah terbukti menurunkan insiden morbiditas demam yang berkaitan dengan adanya endometritis, infeksi luka operasi, dan infeksi saluran kemih.

Penelitian mengenai pemberian antibiotik profilaksis terhadap penyembuhan luka dan kejadian infeksi luka operasi menunjukkan adanya pengaruh. Infeksi yang terjadi pada luka operasi bersih biasanya akan digunakan sebagai dasar untuk memonitor faktor lain yang dapat menyebabkan infeksi luka setelah operasi.

Hasil penelitian ini sesuai dengan penelitian Pratiwi (2012) yang menemukan bahwapengaruh pemberian antibiotik profilaksis terhadap kejadian infeksi luka operasi bersih pasien bedah di RSU PKU Muhammadiyah Bantul dibuktikan dengan nilai Fhitung sebesar 2,940 dengan probabilitas 0,029. Mayoritas 
pasien menggunakan antibiotik profilaksis cetriaxon sebanyak 23 orang $(39,7 \%)$, dan pasien bedah yang tidak terdapat infeksi luka operasi 54 orang $(93,1 \%)$.

Lain halnya dengan antibiotika profilaksis, antibiotika untuk terapi disarankan diberikan pada pasien post sectio caesarea, karena pasien caesar rentan terhadap bakteri yang timbul dari luar maupun dalam. Adanya infeksi post sectio caesarea yang berupa endometritis dan infeksi luka bedah dapat dinilai dari tanda tanda klinis berupa kenaikan suhu tubuh lebih dari $38^{\circ} \mathrm{C}$, uterus lembek dan nyeri tekan, luka berbau atau adanya eritema, pus, adanya indurasi atau infiltrate disertai nyeri tekan, dan kadang - kadang luka operasi terbuka (Mivumbi, 2014).

Menurut teori tepi luka bagian luar secara normal terlihat mengalami inflamasi pada hari ke-2 sampai hari ke-3, tetapi lama kelamaan inflamasi ini akan menghilang dalam waktu 7-10 hari luka dengan penyembuhan normal akan terisi sel epitel dan bagian pinggirnya akan menutup. Apabila terjadi infeksi tepi luka akan terlihat bengkak dan meradang (Kozier, 2012).

\section{F. SIMPULAN DAN SARAN}

\section{Kesimpulan}

Berdasarkan hasil penelitian mengenai gambaran penyembuhan luka operasi post section caesarea dengan pemberian antibiotik ceftizoxime sebagai dosis tunggal di RS SMC Tasikmalaya, maka dapat disimpulkan sebagai berikut:

a. Pemberian antibiotik ceftizoxime sebagai dosis tunggal pada ibu pre operasi sectio caesarea di RS SMC Tasikmalaya sebanyak $100 \%$.

b. Penyembuhan luka operasi ibu pre operasi sectio caesarea di RS SMC Tasikmalaya sebagian besar termasuk kategori sembuh (83\%).

\section{Saran}

a. Bagi Institusi Kesehatan

Hasil penelitian ini dapat menjadi masukan bagi perkembangan asuhan kebidanan dalam menambah sumber informasi mengenai penggunaan antibiotika profilaksis ceftizoxime pada prosedur SC untuk mencegah infeksi dan mempercepat penyembuhan luka.

b. Bagi Institusi Pendidikan Hasil penelitian ini dapat bermanfaat sebagai tambahan informasi di perpustakaan yang dapat dijadikan bahan bacaan bagi mahasiswi kebidanan.

c. Bagi Peneliti Lain

Sebaiknya dilakukan penelitian lebih lanjut yang berkaitan dengan faktor yang mempengaruhi penyembuhan luka post sectio caesarea pada ibu yang diberikan antibiotik profilaksis dosis tunggal ceftizoxime. Adapun faktor lainnya yang mempengaruhi penyembuhan luka adalah usia, nutrisi, medikasi, obesitas, sifat injuri, adanya infeksi dan lingkungan setempat.

\section{G. DAFTAR PUSTAKA}

Asyifa, Suarniant \& Mato, (2017). Faktor-Faktor yang Berhubungan dengan ILO di RSUP DR. Wahidin Sudirohusodo Makassar. Vol 1 no 2. Diakses 10 Oktober (2018 dari http://library.stikesnh.ac.id

Brunner dan Suddart, (2001). Buku ajar keperawatan medikal bedah. Brunner \& Suddarth edisi 8 volume 1.Alih bahasa Waluyo A, Karyasa IM, Julia, Kuncara, Asih Y. Jakarta. EGC

Craven dan Hirnle (2000)

Fundamental Of Nursing : Human Health and Function, Lippincott, Philadelpia.

Cuningham F.G, (2006). Obstetric Williams edisi : 21 hal 591. Jakarta : EGC

Ganiswara dkk., (2009). Farmakologi dan Terapi. Ed.4. Fakultas Kedokteran Universitas Indonesia. Jakarta

Haryanti dkk, (2013). Prevalensi dan Faktor Resiko Infeksi Luka Operasi Bedah. Vol. 15 No 4. Diakses 8 Oktober (2018) dari http://saripediatri.idai.or.id 
Hidayat, 2007. Metode penelitian Kebidanan Teknik Analisis Data. Salemba Medika. Jakarta

Jawetz dkk., (2011). Medical Microbiology. Ed.25. Lange;

Kozier, Barbara. (2010). Buku Ajar Fundamental Keperawaan Konsep, Proses, \& Praktik. Jakarta: EGC

Mansjoer, (2009). Kapita Selekta Kedokteran. Aescepalus. Jakarta

Manuaba, (2012). Memahami Kesehatan Reproduksi Wanita. Jakarta : EGC

Mivumbi, (2014). Prophylactic ampicillin versus cefazolin for the prevention of post-caesarean infectious morbidity in Rwanda, International Journal of Gynecologi and Obstetric. $(2014 ; 1243)$ : 244-247

Mochtar. (2008). Sinopsis Obstetri. Jakarta : EGC

Mutmainah (2014). Evaluasi penggunaan dan efektivitas antibiotik profilaksis pada pasien bedah sesar di Rumah Sakit Surakarta tahun (2010). Jurnal Farmasi Klinik Indonesia $(2014 ; 32)$ : 4449.

National Nosocomial Infection Survailance NNIS) America . (2010) http://www.ajicjournal.org/article/S0196655304)00542-5/ab

Notoatmodjo. 2010. Metodologi Penelitian. Teori dan Aplikasi. Rhineka Cipta. Jakarta

Nuraliyah (2012). Evaluasi Penggunaan Antibiotika Profilaksis Pada Pasien Seksio Sesarea Di Rumah Bersalin Daerah RBD. Panti Nugroho Purbalingga Tahun (2009). Fakultas Farmasi Universitas Muhammadiyah Puwokerto.

Osman (2013). Prophylactic ceftizoxime for elective cesarean delivery at Soba Hospital, Sudan. BMC Research Notes 2013, 6:57. $\mathrm{http} / / \mathrm{www}$. biomedcentral.com/17560500/6/57.

Pandjaitan, (2015). Infeksi Nosokomial di Rumah Sakit harus diantisipasi. diakses 26 September (2018 dari http://politikindonesia.com/
Pratiwi (2011). Pengaruh Pemberian Antibiotik Profilaksis Terhadap Kejadian Infeksi Luka Operasi Bersih Pasien Bedah di RSU PKU Muhammadiyah Bantul

Putra \& Asrizal, (2012). Tindakan Perawat dalam Pencegahan Infeksi Nosokomial luka Pasca Bedah. diakses 11 Agustus (2018)

Ruth Jhonson (2005). Buku Ajar Praktik Kebidanan. Buku Kedokteran EGC. Jakarta

Salamah (2015) Hubungan Mobililsasi Dini dengan Pemulihan Luka Post Sectio Caesarea di Rumah Sakit Panembahan Senpati Bantul. STIKes Aisyiyah Yogyakarta.

Setyarini, Barus \& Dwitari, (2013). Perbedaan Alat Ganti Verband Antara Dressing Set and Dressing Trolley terhadap Resiko Infeksi Nosokomial dalam Perawatan Luka Post Operasi . Diakses pada tanggal 10 September (2018) dari http://www.e-jounal.kopertis4.or.idd

Smail \& Hofmeyr, (2007). Antibiotic prophylaxis for cesarean section (review), The Cochrane database Syst Rev, 2007;(3): CD0030933.

Smeltzer \& Bare, (2001). Buku Ajarmedikal Bedah Brunner dan Suddart Alih Bahasa Monica Ester ed. 8.Jakarta: EGC

Subiston, (2009). Buku Ajar Bedah, diterjemahkan oleh Petrus Andrianto \& Timan I.S, 185-196, Jakarta, EGC.

Sumantri, (2007). Aplikasi Statistika. Pustaka Setia. Jakarta.

Suriadi, (2007). Manajemen Penyembuhan Luka. Pontianak:Stikep Muhammadiyah

Suwardiman, (2007). Dampak Infeksi Luka Operasi Appendiktomi Terhadap Lama Hari Rawat dan Biaya Perawatan di Rumah Sakit Mardi Waluyo Metro Lampung. Tesis. Yogyakarta : Program Pascasarjana Fakultas Kedokteran Universitas Gadjah Mada 
Tjay dan Rahardja, (2012). Obatobat Penting, Khasiat, Penggunaan dan Efek samping. Edisi 5. Gramedia. Jakarta

Valleria, (2009) .Berapa lama penyembuhan

Caesar.http://www.momsmiracle.comdiak ses 24 September 2018.

WHO, (2014). Guideline for ATC Clasification and DDD Assignment, Oslo, Norwey, WHO Colaborating Centre for Drug Statistic Methodologi.

Wiknjsosastro, H. (2010). Ilmu Kebidanan, cetakan ketiga, Jakarta: YBP SP

Yuwono (2013). Pengaruh Beberapa Faktor Risiko Terhadap Kejadian Surgical site infection SSI) Pada Pasien Laparotomi Emergensi. Jambi Medical Journal, diakses pada tanggal 29 September 2018 dari http://eprints.unsri.ac.id/3161/ 